\title{
Traction-assisted circumferential endoscopic submucosal dissection of early esophageal squamous cell carcinoma, followed by metal stent insertion and fixation with a dedicated clip
}

Early esophageal squamous cell carcinoma (SCC) can be curatively resected by endoscopic submucosal dissection (ESD), with R0 resection rates of up to 93.9\% for early lesions [1]. It has significantly lower recurrence rates compared with piecemeal endoscopic mucosal resection [2]. ESD offers similar cure rates for early SCC to those achieved with surgery, but with significantly lower morbidity than esophagectomy [3]. However, ESD can be extremely technically challenging in patients with circumferential esophageal lesions, which often results in such patients being referred preferentially for surgery. Circumferential ESD is also associated with an almost $100 \%$ risk of stricture formation [4]. This video aims to illustrate techniques by which endoscopists can overcome both these challenges.

A 70-year-old man was referred for ESD of a circumferential esophageal SCC. - Video 1 demonstrates the use of the clip-and-line traction technique to help expose the submucosal planes and aid orientation during circumferential resection ( $\triangleright$ Fig. 1 ). One method of reducing stricture formation is placement of a prophylactic self-expandable metal stent (SEMS). The main limitation of using fully covered SEMSs is early stent migration; one way of preventing this is fixation of the stent in place either with clips or endoscopic suturing. - Video 1 also illustrates the safety and feasibility of deploying a SEMS immediately after ESD and the use of a purpose-built over-the-scope Stentfix clip (Ovesco) to hold the stent in place and prevent migration ( $\mathbf{F i g . 2}$ ). The stent was removed 4 weeks later using the Ovesco remOVE system, which consists of a "cutter" operated by a DC impulse.
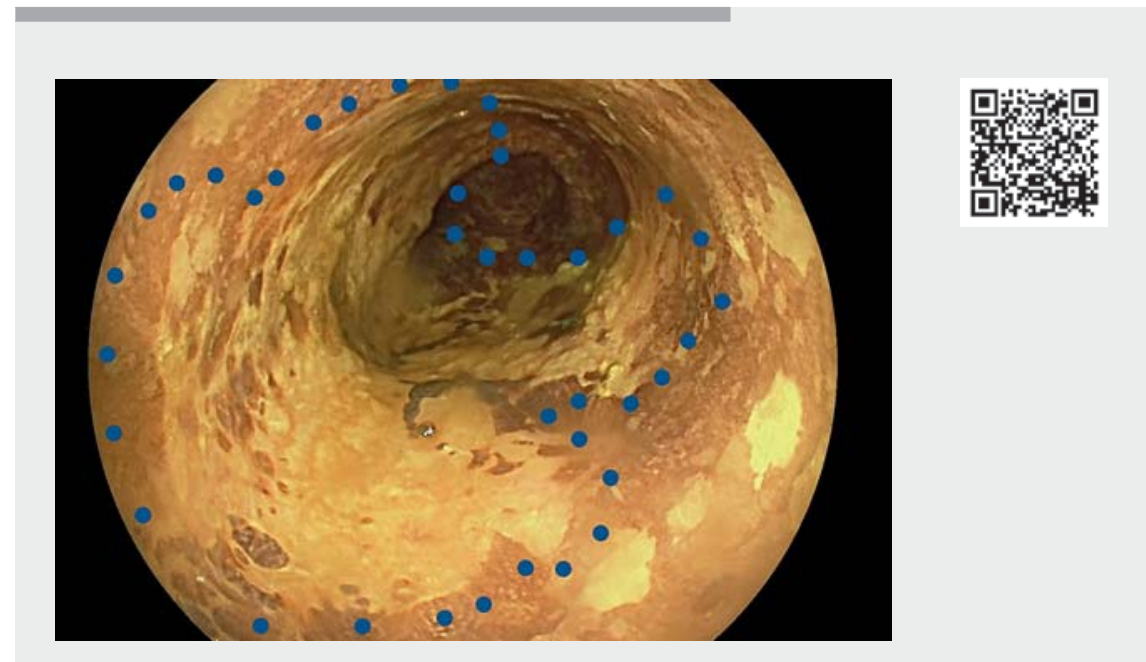

Video 1 A circumferential esophageal squamous cell carcinoma is resected en bloc using the endoscopic submucosal dissection tunnel technique with clip-and-line traction and the inserted self-expandable metal stent is fixed at its proximal end; the clip and stent is are removed 4 weeks later; follow-up endoscopy showing the appearance 4 weeks after removal of the stent.

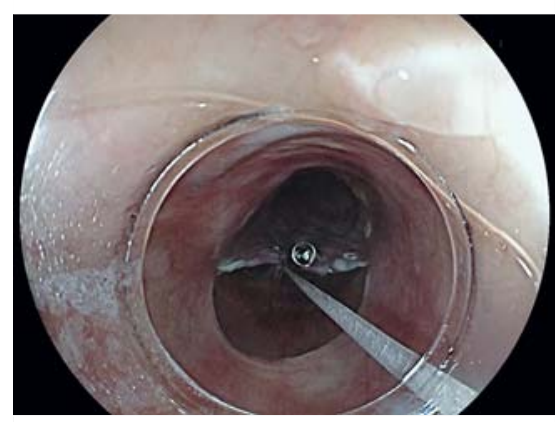

- Fig. 1 Endoscopic image of the clipand-line traction technique being used, in which, outside the patient, a short clip is inserted into the working channel of the gastroscope and a long length of dental floss is tied to the end of the clip; inside the patient, the clip with attached dental floss is deployed on the partially cut flap on the oral side of the lesion, and traction is applied from outside the patient via the dental floss.

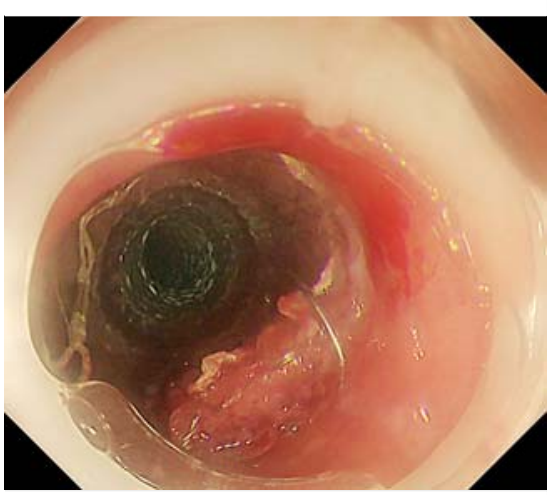

- Fig. 2 Endoscopic view of the over-thescope Stentfix clip (Ovesco) attached to the self-expandable metal stent to hold it in place within the esophagus. 
A follow-up endoscopy 4 weeks after stent removal demonstrated a re-epithelialized esophagus, with a clean scar and subtle narrowing that was easily traversed with an endoscope. We believe that this technique has the potential to become the new standard of care, if proven effective in a larger cohort of patients.

Endoscopy_UCTN_Code_TTT_1AQ_2AD

Competing interests

P. Bhandari has received esearch grants or is the advisory board for Fujifilm, Boston, Olympus, Pentax, 3-D matrix, NEC (Japan), Medtronics.

The authors

Shahila Perveen Aslam, Mohamed Abdelrahim, Hein Htet, Katie Siggens, Patrick Goggin, Pradeep Bhandari

Gastroenterology Unit, Queen Alexandra Hospital, Portsmouth Hospitals NHS Trust, Portsmouth, UK
Corresponding author

\section{Pradeep Bhandari, MD}

Gastroenterology Unit, Queen Alexandra Hospital, Portsmouth Hospitals NHS Trust, Portsmouth, PO6 3LY, UK

Pradeep.bhandari@porthosp.nhs.uk

\section{References}

[1] Repici A, Hassan C, Carlino A et al. Endoscopic submucosal dissection in patients with early esophageal squamous cell carcinoma: results from a prospective Western series. Gastrointest Endosc 2010; 71: 715721

[2] Ishihara R, lishi H, Takeuchi Y et al. Local recurrence of large squamous cell carcinoma of the esophagus after endoscopic resection. Gastrointest Endosc 2008; 67: 799804

[3] Zhang $\mathrm{Y}$, Ding $\mathrm{H}$, Chen $\mathrm{T}$ et al. Outcomes of endoscopic submucosal dissection vs esophagectomy for T1 esophageal squamous cell carcinoma in a real-world cohort. Clin Gastroenterol Hepatol 2019; 17: 73-81

[4] Lewis J], Rubenstein JH, Singal AG et al. Factors associated with esophageal stricture formation after endoscopic mucosal resection for neoplastic Barrett's esophagus. Gastrointest Endosc 2011; 74: 753-760
Bibliography

Endoscopy 2022; 54: E689-E690

DOI 10.1055/a-1722-2206

ISSN 0013-726X

published online 18.2.2022

(c) 2022. Thieme. All rights reserved.

Georg Thieme Verlag KG, Rüdigerstraße 14,

70469 Stuttgart, Germany

\section{ENDOSCOPY E-VIDEOS \\ https://eref.thieme.de/e-videos}

回回 Endoscopy E-Videos is an open access online section,

田: reporting on interesting cases and new techniques in gastroenterological endoscopy. All papers include a high quality video and all contributions are freely accessible online. Processing charges apply (currently EUR 375), discounts and wavers acc. to HINARI are available.

This section has its own submission website at https://mc.manuscriptcentral.com/e-videos 